\title{
Focus Group Discussion-Psychodrama in Corporate Environment: Leverage of Investigation of Employees' Origins of Dissatisfaction within Fludor Benin SA
}

\author{
Djidonou Anselme ${ }^{1}$, Fiossi-Kpadonou Emilie ${ }^{2}$, Hounmènou Jean-Claude Sèdognon ${ }^{3}$, \\ Floret Arthur ${ }^{4}$, Djidonou Lionelle Esméralda ${ }^{5}$, Riboux Alain ${ }^{6}$, Tognon Tchégnonsi Francis ${ }^{1}$ \\ ${ }^{1}$ University of Parakou, Mental Health Department, Parakou, Benin \\ ${ }^{2}$ University of Abomey-Calavi, Mental Health Department, Cotonou, Benin \\ ${ }^{3}$ University of Abomey-Calavi, Psychology and Science Education Department, Abomey-Calavi, Benin \\ ${ }^{4}$ Social Change Socio-Anthropologist, Montreal University, Montreal, Canada \\ ${ }^{5}$ High Institute of Commerce and Management, Cotonou, Benin \\ ${ }^{6}$ Brussels Free University, Faculty of Medicine, Brussels, Belgium \\ Email: *cmpjubile2000@gmail.com
}

How to cite this paper: Anselme, D., Emilie, F.-K., J.-C. Sèdognon, H., Arthur, F., Esméralda, D.L., Alain, R. and Francis, T.T. (2017) Focus Group Discussion-Psychodrama in Corporate Environment: Leverage of Investigation of Employees' Origins of Dissatisfaction within Fludor Benin SA. Open Journal of Psychiatry, 7, 162-175. https://doi.org/10.4236/ojpsych.2017.73015

Received: May 12, 2017

Accepted: July 8, 2017

Published: July 11, 2017

Copyright $\odot 2017$ by authors and Scientific Research Publishing Inc. This work is licensed under the Creative Commons Attribution International License (CC BY 4.0).

http://creativecommons.org/licenses/by/4.0/

\begin{abstract}
Background: Employees' dissatisfaction is as a result of confrontations of two divergent views, compliance with collective labor agreement and the company's profitability requirements. However, the documentation of internal and external environmental impacts on the employees is poor. Our objective was to study workers' origin of dissatisfaction from the negative impact of Fludor Benin SA internal and external environment. Population and methods: It was a cross-sectional study, conducted from $11^{\text {th }}$ September 2013 to $08^{\text {th }}$ January 2014, on Fludor Benin SA employees. Data collection was carried out over ten (10) sessions through administration of Focus Group Discussion modules coupled with psychodrama (FGD-psychodrama) and conducted fortnightly. The module was intended for a group of twelve employees per session. It lasted 2 hours and ended with a game comprising a set of sixteen (16) cards. Each participant's 16-card deck allowed the "player" to identify the likely origin of his dissatisfaction at work. Results: One hundred and twenty (120) employees were expected, but only ninety-nine (99) had participated in the FGD-psychodrama. The rate of participation was $82.5 \%$. The average age of the employees was $35.4 \pm 7.4$ years, while sex-ratio was 23.75 . Average seniority was $9.3 \pm 3.2$ years. The employees' robot profile was: 39 (39.39\%) passive employees, 18 (18.19\%) disappointed employees, 17 (17.17\%) unmotivated employees, 14 (14.14\%) dedicated to the company but barely recognized and $11(11.11 \%)$ unhappy employees. The reasons for dissatisfaction originated
\end{abstract}


from matrimonial home 25 (25.25\%), workplace 23 (23.23\%) and use of drugs 11 (11.11\%). Seventy-seven 77 (77.78\%) employees were satisfied with the FGD-psychodrama modules. Conclusion: FGD-psychodrama may be an effective tool to restore unhealthy corporate atmosphere, help employees to discern the origin of their dissatisfaction and change their perception about stressful situations prevailing in their workplace.

\section{Keywords}

Dissatisfaction, Workplace, Focus Group Discussion-Psychodrama, Fludor Benin SA

\section{Introduction}

On $4^{\text {th }}$ July 2008, Fludor Benin SA achieved ISO 9001 certification: 2008 [1]. But an insurgency from disgruntled employees hampered the progress required for this new hallmark. The pernicious effect of the employees' dissatisfaction was an under-performance and a loss for the company, then the Administration attempted to remedy this through refresher workshops for employees from $04^{\text {th }}$ April to $03^{\text {rd }}$ July 2009. In the long term, an unhealthy atmosphere settled down in the company's main production units. Upon request for our expertise, we administered ten Focus Group Discussion modules [2] coupled each time with psychodrama on the workplace [3] [4]. Each module ended with a 16-card deck for the purpose of helping the employee to determine the origin of his dissatisfaction at work.

\section{Population and Methods}

\subsection{Type and Period of the Study}

It was a cross-sectional study with prospective data collection conducted from $11^{\text {th }}$ September 2013 to $08^{\text {th }}$ January 2014 within Fludor Benin SA factory located in Cana district, Benin.

\subsection{Population and Inclusion Criteria}

The study concerned all 246 employees (national and expatriate) working on the site, regularly employed and known by the factory Human Resources Department. Convenience sampling was preferred because of the accessibility and proximity of employees in the workplace. At each FGD-Psychodrama session were expected twelve participating employees. Thus for the ten (10) sessions of FGD-Psychodrama retained, the total workforce of the expected employees was one hundred and twenty (120). Twenty one (21) employees had not given their consent to participate in the study.

The sample size $\mathrm{N}=120-21=99$.

\subsection{Study Variables}

The only dependent variable was represented by the employee's dissatisfaction. 
Independent variables were represented by: socio-demographic characteristics, the employees "Robot Profile", origins of dissatisfaction at work and employees satisfaction to have participated in the FGD-psychodrama module.

\subsection{Data Collection Tools and Technique}

Data collection was conducted through the administration of FGD-psychodrama to the employees with a 16-card deck for the purpose of helping the employee to determine the origin of his dissatisfaction at work. Group work started with arranging the keys to social success.

Through six preliminary discussions conducted with the employees in the factory based on Philips 6/6 technique [5] [6], we determined 16 perceived origins of dissatisfaction within Fludor Benin SA factory. These 16 origins of dissatisfaction at work were divided in four fields of the individual interpersonal life (Figure 1): Field ${ }^{\mathrm{I}}$ ascendant, Field ${ }^{\mathrm{II}}$ descendant, Field ${ }^{\mathrm{III}}$ professional environment and Field ${ }^{\mathrm{IV}}$, Health and addiction.

\subsubsection{FGD-Psychodrama Toolbox}

It included:

\section{1) Keys to success}

The theme "Keys to success" was explored during a previous employees training workshop on "Adapting to work environment". The participant could discuss with his immediate neighbor to arrange the keys to social success in or-

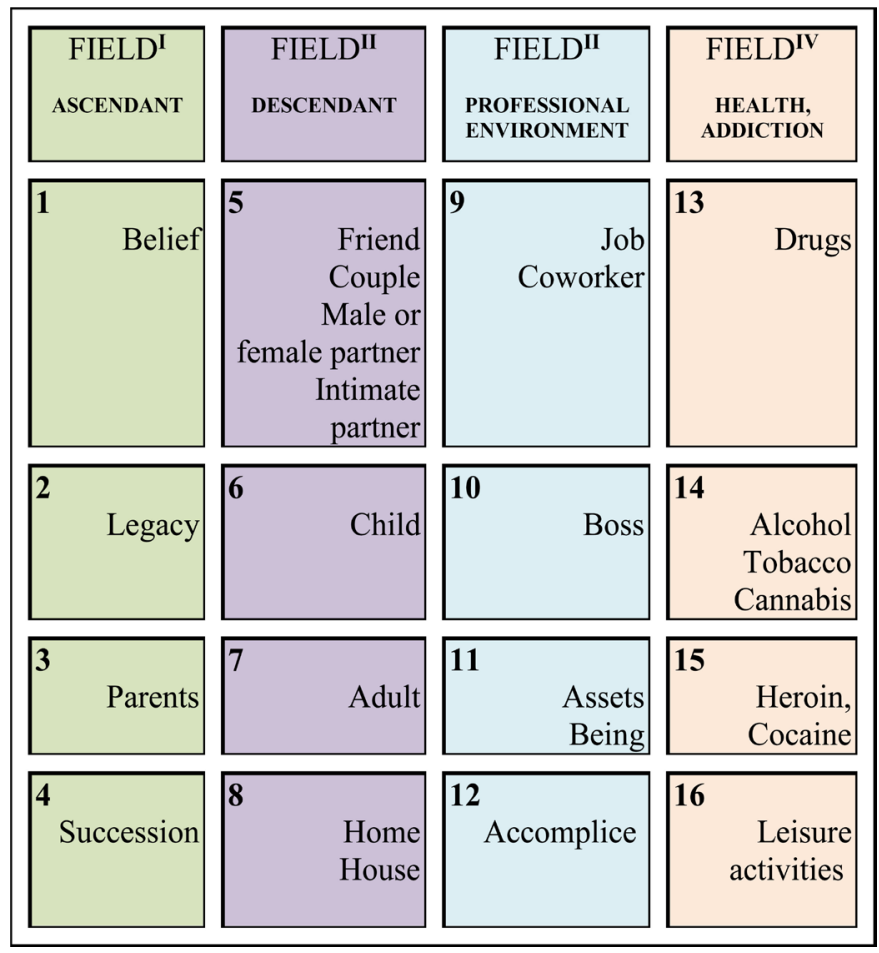

Figure 1. 16 perceived origins of Fludor Benin SA employees' dissatisfaction (logical framework). Source: Djidonou et al. Focus Group Discussion-psychodrama in corporate environment: Leverage of investigation of employees' origins of dissatisfaction within Fludor Benin SA. 


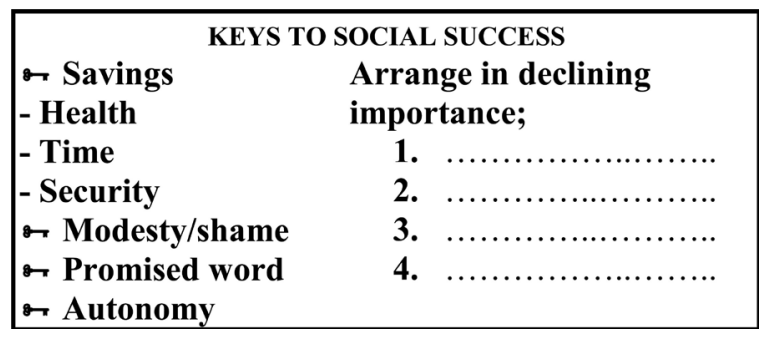

Figure 2. Instruction for arranging keys to social success.

der. Figure 2 below highlighted the instruction on 1/16 of A4 sheet paper handed over to each participant at the session commencement.

\section{2) Slideshow for the facilitation of FGD-psychodrama module}

A slideshow for the facilitation of the module is developed from human ecology [7] themes. Each slide focused on one of the 16 selected likely origins of dissatisfaction and gave the facilitator the possibility to carry out a sensitive communication [8] [9] on dissatisfaction of Fludor Benin SA factory employees brought together within the framework of this session.

\section{3) Kit of 16 batches of 12 cards}

12 represents the total number of participants expected at each FGD-psychodrama module. Each perceived source of dissatisfaction at work was indicated on a playing card. All cards from the same batch represented and indicated the same likely origin of Fludor Benin SA factory employees' dissatisfaction. Then 16 batches of 12 cards were set up. Therefore:

In Field ${ }^{l}$ ascendant, there were: 12 cards indicating Belief as the likely origin of dissatisfaction, 12 cards indicating Legacy as the likely origin of dissatisfaction, 12 cards indicating Parents as the likely origin of dissatisfaction and 12 cards indicating Succession as the likely origin of dissatisfaction.

In Field ${ }^{I I}$ descendant, there were: 12 cards indicating Friend-Couple-PartnerIntimate Partner as the likely origin of dissatisfaction, 12 cards indicating Child as the likely origin of dissatisfaction, 12 cards indicating Adult as the likely origin of dissatisfaction and 12 cards indicating Home-House as the likely origin of dissatisfaction.

In Field ${ }^{I I I}$ professional Environment, there were: 12 cards indicating JobCoworker as the likely origin of dissatisfaction, 12 cards indicating Boss as the likely origin of dissatisfaction, 12 cards indicating Assets-Being as the likely origin of dissatisfaction and 12 cards indicating Accomplice as a the likely origin of dissatisfaction.

In Field ${ }^{\text {IV }}$ health and addiction, there were: 12 cards indicating Drug as the likely origin of dissatisfaction, 12 cards indicating Alcohol-Tobacco-Cannabis as the likely origin of dissatisfaction, 12 cards indicating Heroin-Cocaine as the likely origin of dissatisfaction and 12 cards indicating Leisure activities as the likely origin of dissatisfaction.

The 16 sets of cards were arranged one after the other on a table (Figure 3), positioned away from the group within the workspace. The last step of FGDpsychodrama was meant for each participant to arrange his own 16-card deck 


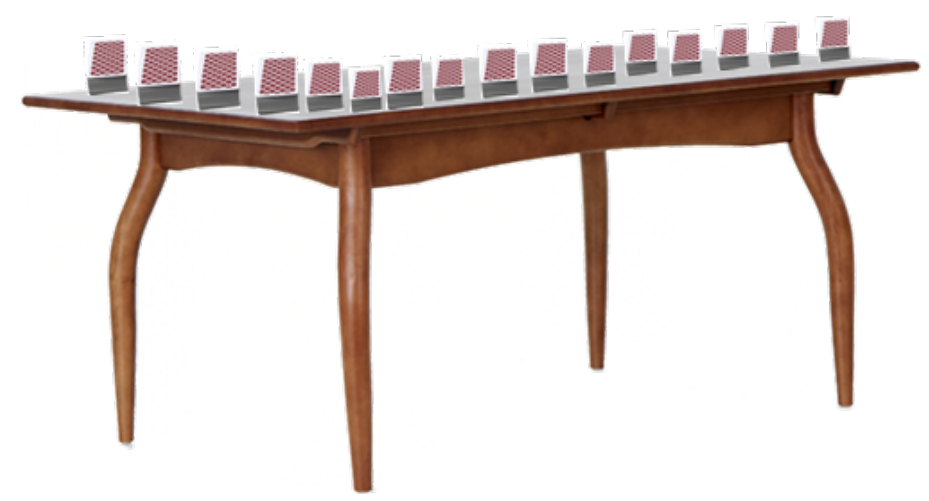

Figure 3. Table of 16 batches of 12 cards/set of FGD-psychodrama.

representing the likely origin of his dissatisfaction at work. For all participants, the principle consisted in: 1) shuffling the 16-card deck, 2) placing at the bottom of the deck the presumed card representing the origin of his dissatisfaction and 3) confronting this presumed card with the first card of the deck.

\subsubsection{Conference Table}

It was used to select the group consensus summaries during FGD-psychodrama sessions.

\subsection{Ethical Considerations and Data Processing}

Data processing procedures were compliant with the ethical principles contained in the World Medical Association Declaration of Helsinki [10]. Data processing and analysis were conducted using Epi Info Version 7. Qualitative variables were expressed in frequency.

\section{Results}

Out of 120 employees of the company expected to be taken through the 10 FGDpsychodrama modules, 99 actually participated, giving $82.5 \%$ as the rate of participation.

\subsection{Socio-Demographic Characteristics of the Employees Interviewed}

The average age of the employees was $35.4 \pm 7.4$ years. There were 95 male employees out of the 99 encountered. The sex-ratio was 23.75. The average seniority was $9.3 \pm 3.2$ years. Figure 4 below highlights the socio-demographic characteristics of Fludor Benin SA factory employees who participated in FGD-psychodrama modules.

\section{2. "Robot" Profile of Employees of Fludor Benin SA Factory}

The robot profile was: 39 (39.39\%) passive employees, 18 (18.19\%) disappointed employees, 17 (17.17\%) unmotivated employees, 14 (14.14\%) dedicated to the company but barely recognized, and $11(11.11 \%)$ unhappy employees. Figure 5 below highlighted the "robot" profile of employees of the Fludor Benin SA factory. 


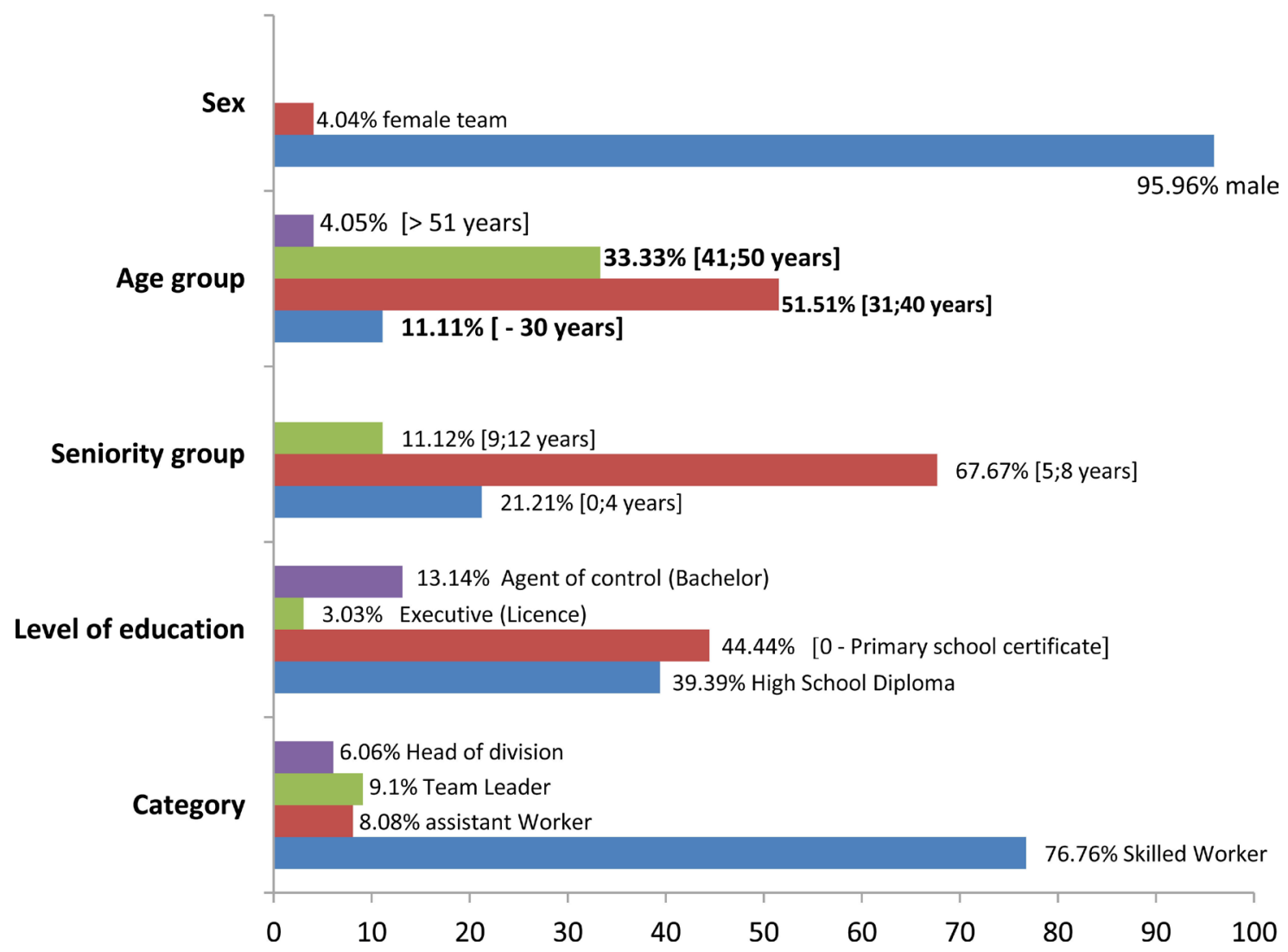

Figure 4. Distribution of the employees of Fludor Benin SA factory based on socio-demographic characteristics.

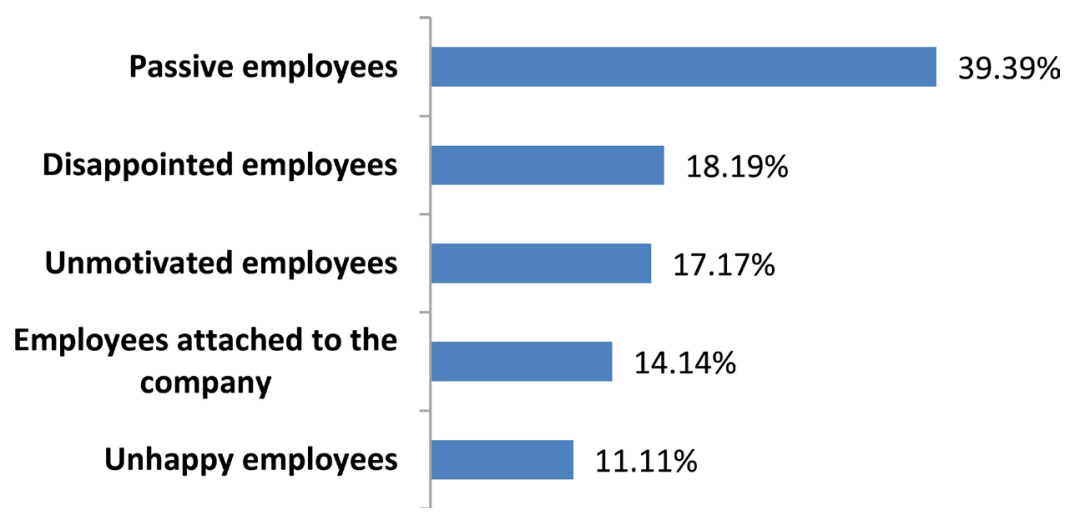

Figure 5. Robot profile of employees of Fludor Benin SA factory.

\subsection{Origins of Dissatisfaction at Work Imperceptible to Fludor Benin SA Employees}

Table 1 below highlighted the origins of dissatisfaction imperceptible to employees.

\subsection{Level of Satisfaction of Fludor Benin SA Employees with Regard to FGD-Psychodrama Module}

Seventy-seven 77 (77.78\%) employees had welcomed the FGD-psychodrama modules. Figure 6 below highlighted the level of satisfaction expressed by Fludor Benin SA employees after participation in FGD-psychodrama module. 
Table 1. Origins of dissatisfaction at work imperceptible to Fludor Benin SA employees.

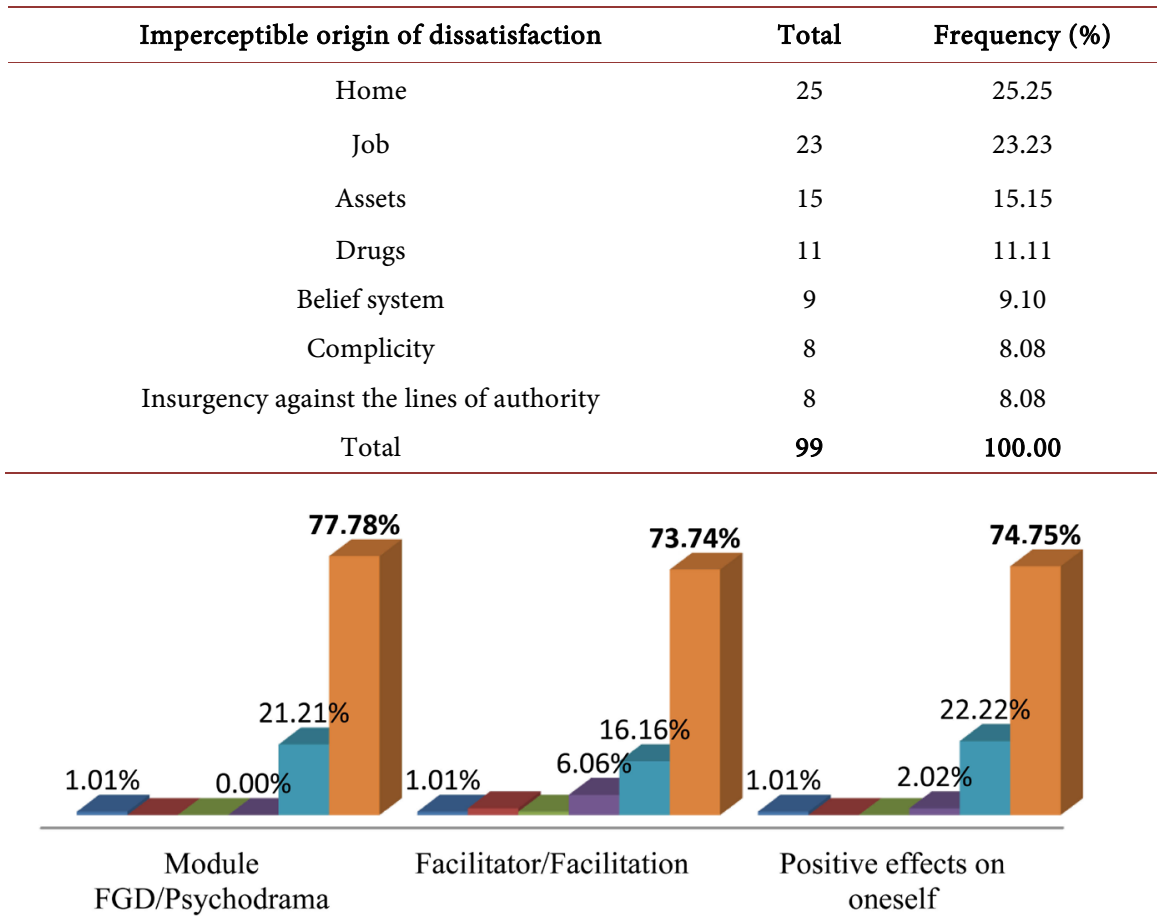

$\square$ Indetermined $\square$ Not at all satified $\square$ Unsatisfied $\square$ Not satisfied $\square$ Satisfied $\square$ Very satisfied Figure 6. Level of satisfaction expressed by the employees who participated in FGDpsychodrama.

\section{Discussion}

\subsection{Limit of Our Study}

\subsubsection{From the Data Collection}

In our study, data collection on employee dissatisfaction was based on confessions likely to lead to prevarication bias.

\subsubsection{Data Processing}

A rigorous statistical study could not be conducted to identify the socio-professsional determinants on which to act in order to reduce employee dissatisfaction. On the basis of the logical framework (Figure 1), it would have been necessary to design the operationalization of the variables and then compare the frequencies using Chi-square test of Karl Pearson or that of Fischer depending on the case with a statistical significance threshold for p less than $5 \%$.

\subsubsection{The Power of Results}

Our specifications received from the management of Fludor Benin SA for this study were aimed at achieving a brief intervention in relation to employee discontent. For this reason, convenience sampling in a small labor force has been preferred to probabilistic sampling. Knowing that probabilistic sampling would give better results.

In addition, workers' discontent could be multifactorial. The FGD-Psychodrama was considered from the perspective of a brief therapy of dissatisfaction 
in the workplace without taking part either for the employee or for the employer. This objective was largely achieved, as demonstrated by the satisfaction of $75.42 \%$ of workers who participated in the FGD-Psychodrama.

\subsection{Participation in FGD-Psychodrama Modules}

For this activity conducted in working environment, ten FGD-psychodrama modules were administered with $98.5 \%$ as rate of participation. The meeting sessions were conducted in a relaxed atmosphere to enable participants express stress at work, their resentment and inability to better adapt to the deafening noise from machines running at full capacity [11].

\subsection{Employees Socio-Demographic Characteristics}

The low representation of women employed on Canna Fludor Benin SA site (Figure 4) would be attributable to the Administration's fear to be faced with issues of "power and desire within the company" [12]. However, no factory will not escape from the assigned social role of diversification based on man-woman complementarity at its place of establishment [13]. The company female employees were the oldest. Dissatisfaction at work seemed to be related to seniority. Davoine [14] reported in his study on the determinants of satisfaction at work that, the oldest employees of a company are not the happiest. They are probably the unhappiest.

\section{4. "Robot" Profile of Fludor Benin SA Factory Employees}

The robot profile of Fludor Benin SA (Figure 5) employees was made up of: disappointed and dissatisfied 18 (18.19\%), demotivated 17 (17.17\%) and ready to terminate their contract with the company when the slightest opportunity arises. Most of them contained their anger which was vented out during the cut and thrust with members of the Administration, or any other employee of the company perceived as undercover agent (both an employee and the Administration informant). The wing of the Trades Union movement to which the employees are implicitly committed was at loggerheads with the Administration. Aside this group, there were those who identified themselves with Fludor Benin SA 14 (14.14\%), but expressed resentment for not being given much recognition. Heads of division were in that category. There remained 39 a proportion of $39.39 \%$ of employees who resigned despite tribulations at work. The company could not rely on them alone to overcome the challenges in a competitive business environment. In studies conducted in work environment in France, the Association for Employment of Executives (APEC) proposed a "cadrotype" [15] which is the different types of Executives within the company. Even though the environments of the study are dissimilar, the ebb and flow [16] of business environment here and elsewhere are not different. APEC recorded 38\% of well fulfilled and motivated Administrative Executives. They represented 14.14\% in our study. Those dissatisfied were $11.11 \%$ of participants to FGD-psychodrama modules in Fludor Benin SA factory. The basis of dissatisfaction seems to origi- 
nate from the paradox of new forms of work organization within the company. While thinking of working for himself, or for his success and pleasure, the employee rather works for his company and his quest for profile. The "do better and more" business attitude which transpires in work organization within Fludor Benin SA, permanently encourages to excel, and this could destabilize the employees [17]. These employees are also overwhelmed by their "good student" Administration in "innovative approach in relation with the growing role of performance assessment as decision-making tools" [18]. Therefore, all components for a change of contemporary capitalism nurturing a systemic economic, financial, social and ecological crisis [19] were met.

\subsection{Origins of Employees Dissatisfaction at Work Imperceptible to Them}

- $25.25 \%$ of the employees interviewed discovered at the end of FGD-psychodrama session that, the origin of their dissatisfaction related to difficulties experienced in their matrimonial home;

- $23.23 \%$ of the employees interviewed discovered that their dissatisfaction was in connection with difficulties from work;

- $15.15 \%$ of the employees interviewed discovered that their dissatisfaction was in connection with assets-related issues. Collovald et al. [20] also recorded the same findings in their research on "improbable mobilizations and study of a trade union directory";

- $11.11 \%$ of employees interviewed discovered that their dissatisfaction was in connection with drugs use ;

- $9.10 \%$ of the employees interviewed discovered that their dissatisfaction came from their relation with their belief system;

- $8.08 \%$ of employees interviewed discovered that their dissatisfaction originated from their complicity as analyzed in "The reinvention of direct action" by Mélo [21];

- $8.08 \%$ of employees interviewed discovered that their dissatisfaction was in connection with their insurgency against the lines of authority as outlined by Serrano-Archimi et al. [22] in "Social audit and organizational change".

Thus, $76.77 \%$ of employees who participated in FGD-psychodrama modules began to realize that the origin of their dissatisfaction at work was elsewhere (Table 1). This dissatisfaction had only subsidiary impact on their transactions within the factory. Self-assessment of the FGD-psychodrama module provides evidence that most participants were interested in the study. Those who were very satisfied recorded $75.42 \%$ as arithmetic average of frequencies (Figure 6).

\subsection{Clinical Vignette; Presentation of the Conclusion of a FGD-Psychodrama Session}

\subsubsection{Participants Profile}

Ten participants were present at the session. They had varying profiles: three laborers, two operators, two technicians, one assistant, one supervisor and one accounting officer. 


\subsubsection{Warming Up}

The preparation of the workplace, participants' arrival and settle-in lasted 15 minutes. Warming up [23] [24] lasted 30 minutes and began by:

- Arranging the "keys to success",

- The session continued with the presentation through slideshow focused on the 16 selected likely origins of dissatisfaction, after the plenary on arranging the keys to social success.

The discussions led to money, husband and wife relationship as well as polygamy:

- Participants complained of their wives whose only concerns were financial issues, and would never be satisfied with the little money they brought home. They purportedly accused them of "dictators" in the couple intimacy;

- Participants reported that their wives felt they were only used to fulfill their husband's sexual desire regardless of their availability;

- They were very compliant at the beginning of conjugal life but then later resorted to the "law of diminishing returns", according to participants;

- They often visited other women after work, especially after the night shift, because their wives couldn't satisfy them. They realized that these women were more caring than their wives at home;

- Polygamy arose from the "bad attitude of the housewife who became "unattractive" and vindictive, shortly after "married life";

- Discussions revealed that the wife's in-laws, supported co-wives cohabitation under the same matrimonial home, for these reasons.

\subsubsection{Psychodrama Game}

Some participants claimed that they were harassed in the night when, as a result of tiredness they were carried away by sleep at their workstation. Then, the discussion focused on "sleep at workstation". Therefore, the theme of the game was set.

The game [25] lasted 30 minutes. The employees agreed to play the "sleep at workstation" game [26] as one of the participants particularly interested proposed the staging.

In the imaginary staging of the game, ancillary egos [3] [27] played by turns: the sleepy employee and the overseer on duty. Four roles were played: the employee falling asleep, the night watchman patrol, the sleepy employee concealing his shoes at his workstation, and the employee waking up from sleep. The atmosphere was recreational and really relaxed. Each of the participants found in the role-play a ground for cooling off [28].

\subsubsection{Echo of the Group of Participants}

The echo of the group lasted 30 minutes. The participants gave their opinion on the game. Each of them related the players' attitudes and utterances to his own experience [29] [30] [31]. Confrontations of the various viewpoints were expressed as well as the definition of sleep, when it carries away the employee at his workstation. This definition varies from one participant to the other. For example, the accountant did not feel concerned by the issue of night shift at the factory. Neither was he a "risk case" [32] subject to much pressure at work. Ac- 
cording to him, job harassment [33] interpreted in the game was oversized. He then invited everyone to adopt preventive sleep attitude at work for the safety of both the employee and his job.

The originator of the role play pointed out:

- Once exhausted, I am likely to sustain injury from the machine running at full capacity.

Another participant replied automatically:

- That's a lame argument of your sleeping at work! Another participant declared;

- Sleeping at work is an issue associated with organization and personal management of rest period according to each employee;

- It comes from imbalanced body equilibrium;

- Why not!!!

Discussions became lively. The employees expressed their viewpoints and broke isolation by identifying themselves in each other's testimonies of [34]:

- It is the individual's relationship with time [35], declared one of the participants;

- It should be taken care of by each of us, another participant exclaimed;

- Sleep increases the risk of professional errors and accidents.

There was a stunned-like silence and the facilitator requested to provide resolutions.

\subsubsection{Time for Resolutions}

Resolutions time was 15 minutes.

Each of the participants was invited to get closer to the playing cards table to form and shuffle his 16-card deck, likely origins of dissatisfaction. During a two-minute break, each participant was invited to conduct self-analysis. Thereafter, he shall place at the end of his trump card (last card) the card representing the origin of his dissatisfaction while choosing a resolution. The following days, and within a short-term, he will have to comply with this resolution willingly undertaken by him, for the purpose of his personal development in relationship with his family and professional environment.

\subsubsection{Cooling Down; Closing}

At the end of the module, the counting of the last cards representing the likely origins of dissatisfaction revealed that three out of ten participants present attributed the professional environment as origin of their dissatisfaction. Upon counting the first cards, two out of ten participants present blamed the professional environment as the origin of their dissatisfaction at work.

The facilitator returned to each of the participants his first card-origin of dissatisfaction on grounds that it was within sight but remained unnoticed. Otherwise, the fact that this first card, positioned at the beginning of the open card-deck within sight of the "holder", right under his nose without being either seen or noticed by him, foreshadowed the participation of the sub-conscious in this whole recreational process. 
Each participant was invited to continue the work initiated on his own scale of personal values.

\section{Overview of FGD-Psychodrama Sessions}

The following were common views expressed by the participants in FGD-psychodrama sessions:

- Work is a paramount value, having a matrimonial home is fundamental, a good friend is a permanent pursuit and a house is a necessity;

- A model employee should have a salary commensurate with the work carried out at the factory and significant compensation for overtime;

- It is important to free the voices in view of eliminating interpersonal grievances;

- Having enough rest prevents wear and tear caused by work;

- Use dialog against harassment at work [36], as it enables to build consensus;

- For team leaders; always remember to call workers to order, rather than blaming them for no apparent reason through triviality and overenthusiasm.

All these discomfort at work undermine the employee's dedication and loyalty to Fludor Benin SA factory.

\section{Conclusion}

The administration of FGD-psychodrama in Fludor Benin SA helped the employee to identify the origin of his dissatisfaction at work, ascertain his responsibility and that of the company organization and focus on the factors to be addressed. This work helps the employee to recognize not only his weaknesses, but also the priority values he should build on to boost his career plan.

\section{Acknowledgements}

Mr. Roland RIBOUX; rep_riboux@yahoo.co.uk

- Chief Executive Officer (CEO), Fludor Benin SA

- Chairman of Benin Council of Private Investors (CIPB)

Standing as the driving force behind the "Focus Group Discussion-psychodrama for business development in Benin", his personal involvement facilitated this work which was highly appreciated by Fludor Benin SA employees. May his desire to extend the experience to the employees of CIPB companies, be implemented for the promotion of mental health at work.

\section{References}

[1] Dick, G.P.M., Inaki, H. and Marti, C. (2008) Shedding Ligth on Causation between ISO 9001 and Improved Business Performance. International Journal of Operation and Production Management, 28, 687-708. https://doi.org/10.1108/01443570810881811

[2] Stewart, D.W. and Shamdasani, P.N. (2014) Focus Groups: Theory and Practice. 3rd Edition, SAGE Publications, Inc., California, CA, 39-139.

[3] Becerril-Maillefert, C. (2013) Psychodrama: The Method of JL Moreno. Editions Eyrolles.

[4] Drakulić, A.M. (2011) Clinical and No-Clinical Setting in First-Session Short-Term 
Psychotherapy Psychodrama Group. Collegium Antropologicum, 35, 173-179.

[5] Peeters, L. (2009) Methods for Teaching and Group Learning. De Boeck Superior.

[6] Gacoin, D. (2010) Chapter 6: The Internal Evaluation of Activities and the Quality of Service Delivery in Practice. Health Guides, 211-290.

[7] Aschan-Leygonie, C. (2011) The Environment under the Eyes of the Society of Human Ecology. Geocarrefour, 86, 3-4.

[8] Heiderich, D. (2011) The Double Game of Sensitive Communication. Sensitive Communication Magazine, 20, 2-11.

[9] Libaert, T. (2008) Sensitive Communication as a Meeting Point for New Configurations of Corporate Communication: An Attempt to Bridge the Gap between the Communicating Organization and the CIS.

[10] World Medical Association (2015) Declaration of Helsinki, 2013. WMA Declaration of Helsinki-Ethical Principles for Medical Research Involving Human Subjects.

[11] Giffard, M. and Moral, M. (2015) Team Coaching: Tools and Practices. 3rd Edition, Armand Colin.

[12] Enriquez, E. (1997) The Games of Power and Desire in the Company. Desclée of Brouwer.

[13] Bereni, L. (2009) Making Diversity a Wealth for the Company. Political Reasons, 3, 87-105.

[14] Davoine, L. (2006) The Determinants of Job Satisfaction in Europe: Importance of Context. Center for the Study of Employment.

[15] Pichon, A. (2008) Chapter 3. Relationship with the Company, Exit from Work and Fear of Unemployment. In: Social Science and Society, 75-106.

[16] Hirata, H. and Kergoat, D. (2017) Social Sex Relationships and Work Psychopathology. Working, 1, 163-203.

[17] Cousin, O. (2009) What Place for Work? Revue Intervention Economiques. Papers in Political Economy, 39, 1-35.

[18] Sambou, C., Guillemaut, S., Morelle, M., Archache, A., Le Corroller, A.G., Perol, D. and Perrier, L. (2017) ISO 9001 Certification from the Directorates of Clinical Research and Innovation: Towards an Extension of the Scope to Economic Evaluations. Journal of Epidemiology and Public Health, 65, 159-167.

[19] Vercellone, C. and Harribey, J.M. (2015) What Place for Work? The Political Economy, 3, 62-75.

[20] Collovald, A. and Mathieu, L. (2009) Unlikely Mobilization and Learning of a Union Directory. Politix, 2, 119-143. https://doi.org/10.3917/pox.086.0119

[21] Mélo, D. (2010) Chapter 2. The Reinvention of Direct Action. In: New Debates, 5671.

[22] Serrano-Archimi, C. and Brasseur, M. (2009) Social Audit and Organizational Change. Humanism and Enterprise, 3, 69-83. https://doi.org/10.3917/hume.293.0069

[23] Daniel, S. (2016) The Social and Cultural Atom in the Age of Social Network. Zeitschrift für Psychodrama und Soziometrie, 15, 213-229. https://doi.org/10.1007/s11620-016-0336-y

[24] Blatner, A. (2013) Warming-Up, Action Methods, and Related Processes. The Journal of Psychodrama. Sociometry and Group Psychotherapy, 61, 43-50. https://doi.org/10.12926/0731-1273-61.1.43

[25] Corcos, M. (2009) Psychodrama Psychoanalytic Individual: Actuality, Indications, Limits. Elsevier Masson, Paris. 
[26] Hogh, A., Hansen, A.M., Mikkelsen, E.G. and Persson, R. (2012) Exposure to Negative Action at Work, Psychological Stress Reactions and Physiological Stress Response. Journal of Psychosomatic Research, 1, 47-52.

[27] Anzieu, D. (2015) Analytic Psychodrama in Children and Adolescents. University Press of France.

[28] McVea, C.S., Gow, K. and Lowe, R. (2011) Corrective Interpersonal Experience in Psychodrama Group Therapy: A Comprehensive Process Analysis of Significant Therapeutic Event. Psychotherapy Research, 21, 416-429. https://doi.org/10.1080/10503307.2011.577823

[29] Guettier, B. (2015) Group Psychodrama: Figurability and Transitionality. In: Body, Gesture and Language, Eres, 207-217.

[30] Maurin, M. and Gimenez, G. (2012) A Practice of Psychoanalytic Psychodrama from Group to Institution: From Individual Counter-Transference to Group Counter-Transference. Review of Psychoanalytic Psychotherapy, 2, 139-150.

[31] Aupetit, D. (2015) Individual Body, Group Body and Institutional Body. In: Body, Gesture and Language, Eres, 219-227.

[32] Petit, J., Dugué, B. and Daniellou, F. (2011) Ergonomic Intervention on Psychosocial Risks in Organizations: Theoretical and Methodological Issues. Human Work, 74, 391-409.

[33] Grébot, E. (2011) Harassment at Work: Identify, Prevent, Defuse. Editions Eyrolles.

[34] Servant, D. (2008) Managing Workplace Stress: Do We Need to Act on the Individual or the Organization? Perspective PSY, 146-148.

[35] Cru, D. (2016) Collective Work and Work: On the Notion of Collective Work. Working, 1, 53-59.

[36] Faulx, D. and Detroz, P. (2009) Psychological Harassment at Work: Relational Processes and Profiles of Victims. In: Process Approach, Integrative and Dynamic of a Complex Phenomenon, Human Work, 155-184.

\section{Scientific Research Publishing}

\section{Submit or recommend next manuscript to SCIRP and we will provide best service for you:}

Accepting pre-submission inquiries through Email, Facebook, LinkedIn, Twitter, etc. A wide selection of journals (inclusive of 9 subjects, more than 200 journals)

Providing 24-hour high-quality service

User-friendly online submission system

Fair and swift peer-review system

Efficient typesetting and proofreading procedure

Display of the result of downloads and visits, as well as the number of cited articles

Maximum dissemination of your research work

Submit your manuscript at: http://papersubmission.scirp.org/

Or contact ojpsych@scirp.org 